\author{
К.Б. Маматова ${ }^{1}$ \\ ${ }^{1}$ КГУСТА им. Н.Исанова,Бишкек, Кыргызская Республика
}

\author{
K.B.Mamatova ${ }^{1}$ \\ ${ }^{1}$ KSUCTA n.a. N. Isanov, Bishkek, Kyrgyz Republic
}

(kymbat2555@mail.ru)

\title{
THE EFFECTIVNESS OF MONOLINGUAL COMMUNICATIVE METHOD IN TEACHING ENGLISH LANGUAAGE
}

\section{ЭФФЕКТИВНОСТЬ МОНОЯЗЫЧНО-КОММУНИКАТИВНОГО МЕТОДА В ОБУЧЕНИИ АНГЛИЙСКОМУ ЯЗЫКУ}

Бул макалада англис тилин окутууда бир тилдүҮ коммуникативдик методдун эффективдүҮлугу жана студенттердин бөтөн тилди түшүнүҮсүнө, ой жүгүртүҮсунө жана сүйлөө речин өстүрүүсүнө багыт бергендиги жөнүндө сөз болот. Омондой эле макланын негизги максаты бөтөн тилди окутууда ар тараптуу окутуунун ыкмаларын колдонуу жана коюлган максатка ийгиликтүҮ жетишүүнүн жслдорун көрсөтүY болуп эсептелет. Англис тилин окутуудагы эн татаал деп мүнөздөлгөн тилди кабыл алууга ийкемдүY жана продуктивдүY тилдик ишмердикке көбурөөк көңүл бурулган.

өзөк сөздөр: бир тилдүY коммуникативдик метод, билим берүY системасы, чет тили, бөтөн тил, кабыл алуудагы продуктивдүҮ сөз ишмердиги, сөздү түшүнүҮ, текстти түзмө-түз которууга жол бербөө.

Эта статья рассматривает эффективность моноязычно-коммуникативного метода в обучении английскому языку в иелях развития навыков позволяющих студентам успешно понимать, разговаривать и думать на не родном языке. Статья также указывает на разнообразие методик преподавания и других иееленаправленных языковых упражнений для достижения продуктивного результата. Большое внимание уделено восприимчивым и продуктивным языковым деятельностям, который характеризуются как самые сложные при изучении английского языка.

Ключевые слова: моно язычно-коммуникативный метод, образовательная система, иностранный язык, не родной язык, восприимчивая и продуктивная речевая деятельность, понимание слов, уклонение от прямого перевода текста

This article is about the effectiveness of monolingual communicative method which makes students to be able to understand, speak and think in nonnative language. It also demonstrates variety of teaching methods and techniques, and other language targeted exercises to succeed in this splendid sphere. Much attention was given to the receptive and productive speech activities, which can be defined as the most difficult ones in studying English language.

Key words: monolingual communicative method, educational system, foreign language, nonnative language, receptive and productive speech activities, word comprehension, preclusion translation of text.

The acquisition-versus-learning debate may seem to be relatively recent argument, yet for as long as languages have been taught people have argued about the best way of doing it, and how to help students to learn more effectively. The great linguist Harold Palmer made a similar distinction between spontaneous and studied capacities in a book published in 1921. And this was just one of many writings before and since which have tried to pin down what makes a good language lesson or effective method [2.46-47]. 
Current teaching practice is the direct result of such argument discussion, and not only on the subject of acquisition and learning. Both abstract theory and practical techniques have been debated, have gone in and out of fashion, and have influenced what was and is included in classrooms and teaching materials.

For a long time humanity is trying to ease their life through improvement and innovation of all spheres of science, and the educational methods of learning foreign languages is not the exception.

Historical analysis of teaching methods presents us the Soviet Union educational system as the most powerful among the others. Though this system is considered to be the best, it has some disadvantages. Students and pupils were provided with practical and theoretical knowledge of exact and humanities science, but the language studying was on the theoretical level, which was the fault of methodologies.

There are many methods of teaching languages. For example, Lexical Approach, Silent way, Community Language Learning, Grammar Translation, Audio-lingualism, Communicative Language Teaching and many others.

Among them Communicative Language Teaching method (CLT) has a lot in common with the Monolingual Communicative one. CLT has two main guiding principles: the first is that language is not just patterns of grammar with vocabulary items slotted in, but also involved language functions such as inviting, agreeing, disagreeing, suggesting, e.t.c. which students should learn how to perform using a variety of language exponents (e.g. we can invite by saying "Would you like to come to the cinema?", "Do you fancy coming to the cinema?", "What about coming to the cinema?", "How about a film?", "Are you on for a film?", e.t.c. Students also need to be aware of the need for appropriacy when talking and writing to people in terms of the kind of language they use (formal, informal, tentative, technical, e.t.c).

The second principle of Communicative Language Teaching is that if students get enough exposure to language, and opportunities for language use and if they are motivated - then language learning will take care of itself. As a result, the focus of much CLT has been on students communicating real messages, and not just grammatically controlled language. The deployment of many communicative activities, where students use all and any language they know to communicate, shows this aspect of CLT at work [4.63-64]..

Communicative Language Teaching has had a thoroughly beneficial effect since it reminded teachers that people learn languages not so that they know about them, but so that they can communicate with them. Giving students different kinds language, pointing them towards aspects of style and appropriacy, and above all giving them opportunities to try out real language within the classroom humanized what had sometimes been too rigidly controlled.

The 21-st century has brought the new wave of methodological novelty. The Monolingual Communicative method of teaching English language has become the top by effectiveness. So what are the main reasons of being internationally successful? The answer to this question is concealed in main purpose of studying languages, which is to make the students to be able to understand, speak and think in nonnative language. This may be reached only by development of receptive and productive speech activities [3.190].

Receptive speech activities are reading and listening, which are used for information gaining, can be defined as less difficult ones, that is why they are the goals itself. Each of these speech activities includes the grammatical and lexical aspects. In comparison with the Soviet Union methods of teaching, when grammar was learnt just for grammar, nowadays it assists in speech making [3.193].

As we cannot use the Russian or other native language for grammar explanation, and students/pupils do not know any word in English we come to the barrier that can be overcome with the help of problem method. This method has the following algorithm of use:

- On the first stage, students will be given clinches as "I am Mike", "I am Mary", "I am a student". 
- On the second stage, students will be given the next clinches with changed pronoun as "He is Mike", "She is Mary", "He/she is a student".

- Third stage is comparative analysis of two sentences as "I am Mike" and "He is Mike". Through this action students will conclude the rule of "to be" usage, according to their own understanding.

Thus, this method gains not only in monolingual mode but in students' activity as well. The intermediate and advanced level student are studying the grammar easier using foreign language, because there is no speaking barrier.

The second aspect is the lexical one. In order to study the words without translation, teacher should use his/her creativity. There are many different variants of new vocabulary presentation. For example: pictures, situational examples, gestures and mimics. At the higher level, teacher can give the definition of new words and students will not only understand, but even will give their own vision of this word comprehension [3.165-167].

Thereby the analysis of two these aspects showed that there is real, productive way of studying the language using just one language, where reading, writing, listening and speaking are used together from the very beginning.

However, there are some problems, connected with correct understanding of words, idioms, sayings and proverbs. The different culture traditions leave traces on the meaning of phraseological units that cause arduous perception. Therefore, after the presentation of meaning through cards, pictures or definition the students should show their correct understanding. Only in such situations, the native language is needed to be used. The students will find the equivalent proverb or saying, which will be evidence of their correct comprehension.

One more crucial issue is ability to think in foreign language. At first sight, it seems to be difficult, but several rules will ease this process. Firstly there is needed to analyze the native language thinking. When children begin learning how to speak, read and write their mind starts to associate the words with objects. For example, when they say "doll" they imagine the definite toy. Even the abstract notions have the object association, but it varies from one person to another. For example, "comfort" - one will imagine plush armchair, another will imagine sofa or bed.

The process of learning the second language is more complicated process. Foreign language learners usually memorize the words through the translation. For example, "ear" Is "yxo". That is the first mistake which can be corrected only when the students will start thinking with the new set of labels. This isn't a concept I came up with all by myself, major language learning companies teach it in their courses. Instead of vocabulary lists, with words in the native language on the side, and the foreign language on the other, they use pictures, pictograms, and symbols to demonstrate a word's meaning [5.113].

The second rule is preclusion translation of texts or dialogues for correct understanding, translation into English language, especially at the starter's level. Regular translation will block the process of foreign speech thinking. Instead of using clichés, labels or imagination of what he/she wants to say, students will translate sentences word for word from the native language in his/her mind [6.144-146].

Out of the second rule courses reasonable question, will students have the ability to translate at all? As it was said, it is advisable not to use translation for comprehension. The translation exercises must be on the intermediate and advanced levels, and must be done just for translation process.

Invention of new classroom practices and approaches to designing language programs and materials reflects a commitment to finding more efficient and more effective ways of teaching languages. The classroom teacher and the program coordinator have a wider variety of methodological opinions to choose from than ever before. They can choose methods and materials according to the needs of learners, the preferences of teachers, and constraints of the school or the educational setting. Methods appear to be used on very different views of what language is and how 
a language is learned. It is an attempt to depict, organize, and analyze major and minor approaches and methods in language teaching, and to describe their underlying nature [1.57-58].

Concluding this paper it should be noted that this method has its difficulties, though if a teacher and a student follow all recommendatoins and rules, the best result will be achieved: correct and fluent speaking, grammatical writing and thinking in foreign language.

\section{Bibliography}

1. Estaire, S. Planning classroom [Text]: a task based approach / S. Estaire, Z. Zanon. Oxford: Macmillan Heinemann, 2003. - 93p.

2. Galskaya, N.D. Foreign Language Modern Teaching Methodology [Text] / N.D.Galskaya. - Moscow, 2003. - 46-48pp.

3. Larsen-Freeman, D. Techniques and Principles in Language Teaching [Text] / D. Larsen-Freeman and Marti Anderson. - Oxford: Oxford University Press, (First edition), 1986. $189 \mathrm{p}$.

4. Maslyko, E.A. Communicative English for Intensive Learning [Text] / E.A. Maslyko. - Minsk, 1998. - 60-65pp.

5. Prabhu, N. Second language pedagogy, Education, Bilingual [Text] / N.Prabhu. Cambridge: Cambridge University Press, 1987. - 153p.

6. Richards, J.C. Approaches and Methods in Language Teaching [Text] / J.C. Richards and T.S. Rodgers. - U.K. Cambridge University Press, 1986. - 169p.

7. Шаршенбек к.Н. Нетрадиционные формы занятий в обучении иностранных языков [Текст] / Шаршенбек к.Н., А.Ж. Сарымсакова // Вестник КГУСТА. - Бишкек: 2018. - №3(61). - c. 67-71.

8. Жумагулова А.Ж. Эффективность отдельных элементов коммуникативной методики обучения английскому языку [Текст] / А.Ж.Жумагулова // Вестник КГУСТА. Бишкек: - 2019. -№1(63). - с.65-70.

9. Сарымсакова А.Ж. Современные технологии и методы в обучении иностранных языков в ВУЗе [Текст] / А.Ж.Сарымсакова, А.Ж. Жумагулова, А.С.Асанова //Вестник КГУСТА. - Бишкек: 2019. - №1(63). - с.83 - 87. 